\title{
CORTISONE IN THE TREATMENT OF DEGENERATIVE JOINT DISEASE OF THE HIP*
}

\author{
BY \\ WILLIAM F. DOWDELL, WALTER M. SOLOMON, \\ ROBERT M. STECHER, and RALPH WOLPAW \\ From the Department of Medicine, Western Reserve University School of Medicine, \\ at Cleveland City Hospital, Cleveland, Ohio
}

(RECEIVED FOR PUBLICATION MARCH 31, 1952)

Degenerative joint disease of the hip, often called osteo-arthritis, or malum coxae senilis, a clinical condition known for the pain and deformity it causes, is the most disabling form of degenerative joint disease.

The cause of the condition is unknown; trauma, an old dislocation of the hip, a slipped epiphysis, Legg-Perthes disease, and senescent degenerative changes have all been suggested (Steindler, 1951) as the most likely factors in its formation.

The pathology comprises fibrillation, erosion, and eburnation of the articulating cartilage and the production of exostoses of bone. The femoral head may show variable degrees of flattening, and cystic changes may be localized in it as well as in the acetabulum. Sclerosis of the acetabular rim is also seen. Later fibrosis of the joint capsule and peri-articular tissue may also occur and lead to further restriction of joint mobility.

Because of the dramatic effects of cortisone in rheumatoid arthritis, its use experimentally in malum coxae senilis seemed worthwhile even though the pathology of the latter disease differs markedly from that of rheumatoid arthritis. This series of experiments was also prompted by the differences in clinical results following treatment of degenerative joint disease (including malum coxae senilis) with ACTH and cortisone as reported in the literature. Hench and others (1950) reported a patient with degenerative joint disease of one knee who received cortisone for the treatment of leukaemia cutis, and noted relief of pain and stiffness of the involved knee. Boots and others (1951) reported the treatment of eleven patients with malum coxae senilis; they observed subjective improvement in ten patients and increased range of motion in all patients. Brown and others (1951) reported their observations after treating eight patients with malum coxae senilis; two were improved, while six obtained neither subjective nor objective benefit. Thorn and others (1951) described alleviation of symptoms in a patient treated with ACTH who had generalized degenerative joint disease with involvement of both hips. Dale $(1950 \mathrm{a}, \mathrm{b})$ reported treating two cases of osteo-arthritis who experienced dramatic relief of symptoms. These published reports suggest the need of a controlled study in the therapeutic evaluation of this condition.

* This investigation was supported in part by the Arthritis and Rheumatism Foundation. 


\section{Material}

Ten patients (see Table) were selected who had definite clinical amd roentgenographic evidence of the disease and showed objective evidence of limited mobility of the hip joint. The ten patients comprised five men and five women (nine white and one Negro), and their age ranged from 48 to 76 years. One hip only was involved in six cases, and both hips in the other four. Pain referable to one or both hips had been present for 1 to 5 years in 50 per cent. of the patients, and for 6 to 32 years in the other 50 per cent.

TABLE

Results of Treatment in Ten Patients

\begin{tabular}{|c|c|c|c|c|c|c|c|c|c|c|c|c|}
\hline \multirow{3}{*}{ Patient } & \multirow{3}{*}{ Age } & \multirow{3}{*}{ Sex } & \multirow{3}{*}{$\begin{array}{l}\text { Dura- } \\
\text { tion } \\
\text { of } \\
\text { Com- } \\
\text { plaint } \\
\text { (yrs) }\end{array}$} & \multirow{3}{*}{$\underset{\text { Involved }}{\text { Hips }}$} & \multicolumn{6}{|c|}{ Range of Motion of Involved Hip (degrees) } & \multirow{2}{*}{\multicolumn{2}{|c|}{$\begin{array}{c}\text { Subjective } \\
\text { Improvement }\end{array}$}} \\
\hline & & & & & \multicolumn{3}{|c|}{ Placebo } & \multicolumn{3}{|c|}{ Cortisone } & & \\
\hline & & & & & Before & After & $\begin{array}{l}\text { Flexion } \\
\text { Change }\end{array}$ & Before & After & $\begin{array}{l}\text { Flexion } \\
\text { Change }\end{array}$ & Placebo & Cortisone \\
\hline S.S. & 76 & $\mathbf{M}$ & 15 & Both & $130-170$ & $136-171$ & -6 & $130-170$ & $123-175$ & +7 & Yes & Yes \\
\hline A.L. & 59 & $\mathbf{M}$ & 5 & One & $97-180$ & $85-180$ & +12 & $85-180$ & $85-180$ & 0 & No & Yes \\
\hline P.S. & 58 & $\mathbf{F}$ & 6 & One & $140-180^{\circ}$ & $124-180$ & +16 & $124-180$ & $135-180$ & -11 & Yes & Yes \\
\hline C.L. & 60 & $\mathbf{F}$ & 27 & Both & $115-180$ & $113-180$ & +2 & $113-180$ & $110-180$ & +3 & Yes & Yes \\
\hline H.W. & 71 & $\mathbf{F}$ & 6 & One & $85-180$ & $80-180$ & +5 & $90-180$ & $80-180$ & +10 & No & Yes \\
\hline E.F. & 43 & $\mathbf{M}$ & 2 & Both & $85-180$ & $85-180$ & 0 & $85-180$ & $95-180$ & -10 & No & Yes \\
\hline B.K. & 48 & $\mathbf{F}$ & 3 & One & $70-180$ & $100-180$ & -30 & $100-180$ & $85-180$ & +15 & Yes & No \\
\hline J.D. & 69 & $\mathbf{M}$ & 4 & One & $83-175$ & $83-175$ & -2 & $85-178$ & $90-178$ & -5 & Yes & Yes \\
\hline J.J. & 63 & $\mathbf{M}$ & 3 & One & $120-180$ & $110-180$ & +10 & $115-180$ & $120-180$ & +5 & No & No \\
\hline L.L. & 64 & $\mathbf{F}$ & 6 & Both & $145-170$ & $123-175$ & +20 & $125-175$ & $115-175$ & +10 & Yes & Yes \\
\hline
\end{tabular}

\section{Procedure}

Before therapy was begun a red blood count, haemoglobin test, white blood count, differential, sedimentation rate, haematocrit, and urine analysis were undertaken. A complete physical examination was made, including roentgenograms of the hips and chest. The mobility of each hip was measured before and at weekly intervals during the study.

All patients were started on a placebo preparation which was continued for 22 days; this consisted of a raspberry syrup and potato starch mixture containing a very small amount of quinine which imparted the bitter taste simulating the cortisone solution. After completion of the placebo therapy, a cortisone preparation $(25 \mathrm{mg}$. per $5.0 \mathrm{ml}$.) was started on all patients and continued for 22 days; this, too, was dispensed in a raspberry syrup and potato starch mixture. The cortisone was used in a dosage known to give relief to patients with rheumatoid arthritis, namely, $300 \mathrm{mg}$. the first day in divided doses 6-hourly, $200 \mathrm{mg}$. the second day, and $100 \mathrm{mg}$. thereafter for 20 days. All the patients except one were unaware of the nature of the drug used in the study.

All patients were studied as out-patients and seen at regular weekly intervals. At each visit the hip joint was measured for mobility, objective observations were made for any other increased function of the involved joint, and subjective responses were also noted, all measurements and observations being made by the same individual during the entire study.

\section{Representative Case Histories}

Case 1, J.D., 69-year-old white male, with a history of a painful and disabling right hip of 5 years' duration and without any known cause. His general health was good. He was able to flex the hip to an angle of $83^{\circ}$ with the trunk, but found it difficult to cross the right leg over the left or to tie the lace of his right shoe. He was unable to continue 
his work as a school watchman because of the walking and stair climbing. Roentgenograms of the right hip revealed a narrowed joint space, sub-cortical cystic areas in both ilium and femoral head, and sclerosis of the adjacent margins of the acetabulum. While receiving the placebo therapy the patient stated that he felt better and experienced a sensation of warmth over the right thigh. Objectively, the joint mobility remained the same. While receiving cortisone he continued to have less pain, but failed to demonstrate any increased mobility of the joint. Since both the subjective and the objective responses to the placebo and to cortisone therapy were essentially the same, the final result was considered negative.

Case 2, J.J., 63-year-old white male, complained of a painful right hip with inability to cross the right leg over the left or tie the laces of his right shoe. The condition was of 3 years' duration and had no known cause. His general health was good. Flexion of the right hip was measured at $120^{\circ}$ with the trunk. Roentgenograms revealed marked narrowing of the joint space of the right hip, flattening of the femoral head, and sclerosis of the acetabulum. No subjective improvement was noted during either placebo or cortisone treatment. A $10^{\circ}$ increase in flexion was noted while the patient was receiving the placebo, but no objective improvement was seen while he was on cortisone.

Case 3, L.L., 64-year-old white female, gave a history of having had a fall 5 years previously and having noted the onset of pain in the left hip several months later. The condition progressed and one year later caused the patient to stop working. Her general health was good. Roentgenograms revealed changes typical of severe degenerative joint disease of both hips. The right hip flexed to $145^{\circ}$. Shortly after the placebo therapy was started the patient said she had less pain and showed increased flexion of the right hip to $125^{\circ}$. While she was receiving cortisone, partial relief of pain continued and further increase in flexion of the right hip to $115^{\circ}$ was noted. Even after cortisone was discontinued the subjective improvement of less pain and increased agility continued.

\section{Results}

The response in the remaining seven patients was similar to the three cases described above. Out of the total of ten patients, six showed subjective improvement during the control period and eight during the cortisone period. Subjective improvement consisted of a sense of well-being or euphoria, less pain, less stiffness, a feeling of ease in walking, etc. Objective response (see Table) consisted of increased mobility of the joint as measured with a goniometer.

During the control period the objective changes in the joint motion of the ten patients studied varied from decreases of as much as $30^{\circ}$ to increases of as much as $20^{\circ}$. The increase in joint motion in five patients varied between $2^{\circ}$ and $16^{\circ}$, and one patient showed an increase of $20^{\circ}$; three patients showed decreases of $2^{\circ}, 6^{\circ}$, and $30^{\circ}$ respectively; one showed no objective change at all.

During the cortisone treatment period increases in joint motion were seen in six patients, and varied from $5^{\circ}$ to $15^{\circ}$; three patients showed a decreased motion of $5^{\circ}, 10^{\circ}$ and $11^{\circ}$ respectively; one patient showed no objective change at all.

It should be noted that the increases and decreases in joint mobility observed during both the control and cortisone treatment periods were not appreciably different. The increases are probably not clinically significant, for increases of the extent observed are not infrequently seen and may probably be attributed to daily variations in the patient, plus errors of measurement used including the personal error of the observer. The greatest increase, one of $20^{\circ}$, was observed during the control period, but otherwise all the increases were essentially the same. The fact that the patients did equally well while receiving the placebo may represent 
increased effort to help themselves such as is often observed when any new therapy is instituted.

In brief, the Table shows that six patients noted subjective improvement while on the placebo as compared with eight patients while on cortisone. Subjective improvement was usually of greater degree in the cortisone-treated patients. Objectively, the increases in mobility noted in the ten patients during both placebo and cortisone periods were essentially the same. On critical analysis, the objective improvement noted during the placebo period was slightly greater than that observed during the cortisone period. This may be explained by the fact that the placebo was the first form of treatment tried.

\section{Comment}

Medical treatment of malum coxae senilis has in the past been unsatisfactory. Recently the discovery of cortisone and our increasing knowledge of the physiology of the connective tissue has thrown some light on the mechanism and probable aetiology of the various collagen diseases and of rheumatoid arthritis in particular. In rheumatoid arthritis the use of cortisone is often followed by dramatic results, and although the pathology of degenerative joint disease differs from that of rheumatoid arthritis the clinical use of cortisone in malum coxae senilis seemed worthy of trial.

The results of this study of a small number of cases indicate that in degenerative joint disease of the hips the objective improvement manifested by increased motion of the joint is essentially the same after cortisone treatment as after when a placebo is used. The failure to obtain significant improvement in motion might be explained by the presence of irreversible intra-articular and peri-articular pathologic processes.

Although the cause of pain in this condition is unknown, it is of interest to note that eight of the ten cortisone-treated patients experienced partial relief of pain and noted other subjective signs of improvement, whereas during the control period a decrease in pain and subjective improvement was noted in only six of the ten patients. The mechanism of pain relief are unknown; an anaesthetic effect has been claimed for some of the steroids (Selye, 1941), and Grokoest and associates (1951) feel that relief of pain in rheumatoid arthritis and similar diseases evolves from a suppression of the inflammatory reaction in the host and not from a central or peripheral analgesic effect. Then, too, the subjective response may be related to the sense of well-being or euphoria seen in some patients receiving cortisone. The relief of pain obtained on administration of cortisone was greater than that obtained by the same ten patients during the control period. However, the pain relief and increase in joint motion when present in no case approached the dramatic levels of improvement seen in many patients with rheumatoid arthritis. The use of the same patients as controls also made clear the subjective and objective results which may appear during the administration of a placebo. The improvement noted during the control period tends to detract from the clinical benefit obtained from cortisone, but does not necessarily invalidate these results. The subjective responses, although incapable of measurement were significantly greater in the cortisone-treated patients than in the same patients when treated with the 
placebo. It is clear that partial relief of pain without a clinically significant increase in the mobility of the involved hip is seen in cases of malum coxae senilis treated with cortisone.

\section{Summary}

(1) Ten patients with malum coxae senilis received first a placebo and later oral cortisone.

(2) Partial relief of pain was noted in eight of the ten patients while receiving cortisone, and in six of the ten patients while receiving the placebo.

(3) No clinically significant objective increase in mobility of the joint could be attributed to the use of cortisone.

(4) No untoward symptoms or reactions to cortisone were noted.

(5) The routine use of cortisone in malum coxae senilis cannot be recommended in view of the small improvement observed in the ten patients studied.

\section{REFERENCES}

Boots, R. H., Yen, L. C., McMorrow, K. J., and Ragan, C. (1951). J. Amer. med. Ass., $147,549$.

Brown, C. Y., Jessar, R. A., and Hollander, J. L. (1951). Ibid., 147, 551.

Dale, M. (1950a). J. Mich. med. Soc., 49, 1068.

(1950b). Ibid., 49, 1035.

Grokoest, A. W., Vaillancourt, deGuise, Gottsegen, R., and Ragan, C. (1951). J. clin. Invest., $30,644$.

Hench, P. S., Kendall, E. C., Slocumb, C. H., and Polley, H. F. (1950). Arch. intern. Med., 85, 545.

Selye, H. (1941). Proc. Soc. exp. Biol., N.Y., 46, 116.

Steindler, A. (1951). Amer. Acad. orthop. Surg. Instructional Course Lect., 8, 187.

Thorn, G. W., Forsham, P. H., Frawley, T. F., Hill, S. R., Roche, M., Staehelin, D., and Wilson, L. D. (1950). New Engl. J. Med., 242, 865.

\section{La cortisone dans le traitement de la dégénérescence articulaire de la hanche}

\section{RÉSUMÉ}

(1) Dix malades atteints de coxalgie sénile reçurent par voie buccale d'abord une substance inerte et plus tard de la cortisone.

(2) Un allegement partiel de la douleur fut noté chez 8 d'entre eux lors de l'administration de la cortisone et chez 6 lors de l'administration de la substance inerte.

(3) On n'observa aucune augmentation cliniquement signifiante de la motilité articulaire attribuable à la cortisone.

(4) On ne nota pas de symptômes ou de réactions néfastes dus à la cortisone.

(5) En raison de la faible amélioration chez les dix malades étudiés, l'emploi régulier de la cortisone dans la coxalgie sénile n'est pas recommandé.

La cortisona en el tratamiento de la enfermedad degenerativa de la articulación coxo-femoral

\section{SUMARIO}

(1) Diez enfermos con coxalgia senil recibieron por vía oral primero una substancia de control y luego cortisona.

(2) Un alivio parcial del dolor fué observado en ocho de ellos durante la administración de la cortisona y en seis durante la administración del producto inerte.

(3) No se vió aumentación clínicamente significante de la movilidad articular que se pudiera atribuir a la cortisona.

(4) No se notó síntomas o reacciones desfavorables debidos a la cortisona.

(5) Por ser poca la mejoría en los diez enfermos estudiados, el empleo regular de la cortisona en la coxalgia senil no se recomenda. 